\title{
Revisiting Rapa Nui (Easter Island) "Ecocide"
}

\author{
Terry L. Hunt ${ }^{2,4}$ and Carl P. Lipo ${ }^{3}$
}

\begin{abstract}
Easter Island (Rapa Nui) has become widely known as a case of "ecocide," where the ancient Polynesians recklessly destroyed their environment and, as a consequence, suffered collapse. In recent publications, both popular and academic, scholars have promoted this perspective, drawing upon archaeological evidence and offering Rapa Nui as a parable for our current global crisis. In this paper we address recent claims and outline emerging archaeological and paleoenvironmental evidence. We consider chronology, causes and consequences of deforestation, agricultural strategies, statue transport, and the evidence for ancient population size and its demise. Although deforestation and ecological catastrophe certainly unfolded over the course of the island's prehistory, the ensuing demographic and cultural collapse followed European contact and resulted from the devastating effects of disease and slave trading. Deforestation and contact-induced demographic collapse were separated in time and causation. Finally, we offer alternative perspectives emerging from a variety of recent research.
\end{abstract}

IN HIS RECENT best-selling book, Jared Diamond (2005) further popularized a story of ancient Easter Islanders recklessly destroying their environment and, as a direct consequence, destroying their civilization. Diamond calls this ecological self-destruction "ecocide" and offers Rapa Nui as a parable for our current global environmental crisis. The notion that ancient Polynesians of Rapa Nui committed "ecocide" has been widely shared in public statements (e.g., Young 1991, Gee 2004) and academic literature (e.g., Redman 2001, Flenley and Bahn 2002, 2007, De Monocol et al. 2005). Indeed the theme of Rapa Nui's self-destruction with deforestation induced by large-scaled investments in megalithic statuary and architecture pervades a multidisciplinary academic litera-

\footnotetext{
${ }^{1}$ Manuscript accepted 1 February 2009.

${ }^{2}$ Department of Anthropology, University of Hawai' $i$ at Mānoa, 2424 Maile Way, Honolulu, Hawai'i 96822.

${ }^{3}$ Department of Anthropology and Institute for Integrated Research in Materials, Environments, and Society, California State University at Long Beach, 1250 Bellflower Boulevard, Long Beach, California 90840.

${ }^{4}$ Corresponding author (e-mail: thunt@hawaii.edu).
}

Pacific Science (2009), vol. 63, no. 4:601-616

(C) 2009 by University of Hawai'i Press

All rights reserved ture (e.g., Brander and Taylor 1998, Dalton and Coats 2000).

Close examination of the Rapa Nui evidence from archaeology, paleoenvironmental work, and biological anthropology demonstrates that although the island suffered an ecological catastrophe, the story of "ecocide" may be little more than a modern myth (Rainbird 2002, Peiser 2005, Hunt 2006, 2007, Hunt and Lipo 2007, 2008). After publication of Collapse, many new details have come to light with continuing field research on the island. This new research casts doubt on previous assertions about the sequence and timing of events in the island's prehistory (see Lipo and Hunt 2005, Barnes et al. 2006, Hunt 2006, 2007, Hunt and Lipo 2006, 2007, 2008). New details on the island's chronology, settlement patterns, subsistence systems, and environmental change have led researchers to question "ecocide," instead raising alternatives to scientific and public audiences (e.g., Gibbons 2006, Hunt 2006).

In a recent essay in Science, Jared Diamond (2007) reiterated the account given in his book Collapse and defended his claims against new evidence that challenges a nowconventional view of "ecocide." Like Diamond, Flenley and Bahn (2002, 2007) have also continued their steadfast support for an ecocide story of the island's prehistory. 
In this paper, we respond primarily to $\mathrm{Di}$ amond's (2007) recent framing of the evidence in defense of his views previously published (Diamond 1995, 2005). A detailed response to Flenley and Bahn (2007) can be found elsewhere (Hunt and Lipo 2007). We do not question whether prehistoric deforestation transformed Rapa Nui but instead ask if this deforestation caused population collapse before European contact. We argue that researchers cannot uncritically accept interpretations made of the archaeological and historical records without evaluating the evidence and weighing alternative hypotheses. In doing our best to understand and explain the past, we must open our minds to possibilities that may not find obvious analogies in our contemporary world, particularly if we are to learn something new (and different) from the past. Surely this is the promise and strength of archaeology, and science more generally.

\section{THE CONVENTIONAL INTERPRETATION AND "ECOCIDE"}

Visiting Rapa Nui for a single day in April 1786, the French explorer La Pérouse speculated that at some distant time the island's inhabitants had the imprudence to cut down all their trees. La Pérouse lamented that loss of trees exposed the soil to hot sun, dried up streams, and desiccated the land, making the island almost uninhabitable. He wrote that the islanders "were indebted to the imprudence of their ancestors for their present unfortunate situation" (1798:318-319). After decades of modern field research, contemporary writers tell a similar story (e.g., Flenley and Bahn 2002, Diamond 2005) (Table 1). Diamond (1995:68) captured what he has called "ecocide" by arguing that "Eventually Easter's growing population was cutting the forest more rapidly than the forest was regenerating. The people used land for gardens and wood for fuel, canoes, and houses - and of course, for lugging statues. As forest disappeared, the islanders ran out of timber and rope to transport and erect their statues. Life became more uncomfortable-springs and streams dried up, and wood was no longer available for fires.... As we try to imagine the decline of Easter's civilization, we ask ourselves, 'Why didn't they look around, realize what they were doing, and stop before it was too late? What were they thinking when they cut down the last palm tree?"

\section{EVALUATING THE EVIDENCE}

No one denies that Rapa Nui was largely deforested by the time Europeans first arrived in 1722. The earliest visitors remarked on the dearth of trees or wood available on the island. Evidence from pollen and charcoal identifications show that more than 20 woody taxa once grew on the island (Orliac 2000, 2003). Field research has shown that several million giant palm trees (Fubaea sp. or Paschalococos disperta) once dominated the vegetation over much of the island (Mieth and Bork 2004, 2006). The palms and other woody taxa appear to have declined from about A.D. 1280 and disappeared by about A.D. 1650 , with some remnants surviving into historic times (Hunt 2007). The fact that deforestation occurred is not in question, nor is its association with human activities (contrary to arguments for a major role of climate in causing deforestation as well as cultural changes, see Nunn et al. [2007]). Rather, the conventional interpretations (e.g., Diamond 1995, 2005, 2007, Flenley and Bahn 2002) for the consequences of deforestation (i.e., demographic and cultural collapse) are not supported in the archaeological and historical records. We do not find unambiguous evidence for a huge population that crashed as the consequence of deforestation before European contact. Although the ancient population of Rapa Nui certainly contributed to the island's deforestation, they do not appear to have committed "ecocide" as recounted in the conventional scenario.

\section{Deforestation and Its Consequences}

Diamond (2007) and others (e.g., Flenley and Bahn 2002) believe that the end of the forest brought huge losses for the islanders, but they assume that the palms and other trees were integral to Polynesian subsistence. 
TABLE 1

Comparative Dimensions of Conventional and Revised Models for Rapa Nui Prehistory

\begin{tabular}{|c|c|c|c|}
\hline Dimension & Conventional $^{a}$ & Revised & References $^{b}$ \\
\hline Colonization date & A.D. $400-800$ & $\sim$ A.D. $1200^{c}$ & Hunt and Lipo $(2006,2008)$ \\
\hline $\begin{array}{l}\text { Archaeological visibility } \\
\text { of colonization and } \\
\text { early settlement }\end{array}$ & $\begin{array}{l}\text { Largely invisible record } \\
\text { for } 400-800 \text { years }\end{array}$ & $\begin{array}{l}\text { Almost immediate; visibility } \\
\text { depends on age } \\
\text { resolution and nature of } \\
\text { the record }\end{array}$ & $\begin{array}{l}\text { Hunt and Lipo (2006, 2007, } \\
\text { 2008); cf. Anderson } \\
\text { (1995), Wilmshurst et al. } \\
\text { (2008) }\end{array}$ \\
\hline $\begin{array}{l}\text { Human population } \\
\text { growth rate, size }\end{array}$ & $\begin{array}{l}\text { Slow }(\sim 1 \% ?) \\
15,000+\max .\end{array}$ & $\begin{array}{l}\text { Rapid }(\sim 3 \% \text { ?), logistic } \\
\text { growth rate but reaching } \\
\text { about } 3,000-4,000 \text { ? max. }\end{array}$ & $\begin{array}{l}\text { Birdsell (1957); see early } \\
\quad \text { historic population } \\
\text { estimates (McCall 1994) }\end{array}$ \\
\hline $\begin{array}{l}\text { Deforestation and } \\
\text { ecological impacts }\end{array}$ & $\begin{array}{l}\text { Caused by reckless use of } \\
\text { fire and felling (to move } \\
\text { moai); impacts } 800-400 \\
\text { years after colonization, } \\
\text { then sudden and massive }\end{array}$ & $\begin{array}{l}\text { Caused by rats, fire, and } \\
\text { some felling (but palms } \\
\text { not likely used moving } \\
\text { moai); impacts begin } \\
\text { immediately, but some } \\
\text { forest persists } 400 \text { years } \\
\text { +?; historic impacts from } \\
\text { intensive sheep ranching }\end{array}$ & $\begin{array}{l}\text { Hunt (2006, 2007), Mieth } \\
\text { and Bork (2006); see also } \\
\text { Athens et al. (2002), } \\
\text { Wilmshurst et al. (2008) }\end{array}$ \\
\hline $\begin{array}{l}\text { Resource loss, subsistence } \\
\text { change }\end{array}$ & $\begin{array}{l}\text { Major, loss of trees as } \\
\text { food source and for } \\
\text { canoes providing access } \\
\text { to deep-sea fishing; soil } \\
\text { depletion/erosion }\end{array}$ & $\begin{array}{l}\text { Negligible, palms did not } \\
\text { provide major food } \\
\text { source given rat impacts; } \\
\text { island never had suitable } \\
\text { trees for seaworthy } \\
\text { canoes; depletion/ } \\
\text { erosion of already } \\
\text { nutrient-poor soils; some } \\
\text { historic soil erosion }\end{array}$ & $\begin{array}{l}\text { Orliac (2000), Louwagie et } \\
\text { al. (2006), Hunt (2007) }\end{array}$ \\
\hline $\begin{array}{l}\text { Competition, social } \\
\text { conflict }\end{array}$ & $\begin{array}{l}\text { Warfare (including moai } \\
\text { toppling), cannibalism }\end{array}$ & $\begin{array}{l}\text { "Détente," "signaling," } \\
\text { and smaller-scale } \\
\text { conflicts (most moai } \\
\text { toppled historically, by } \\
\text { an earthquake?); little } \\
\text { physical evidence for } \\
\text { cannibalism }\end{array}$ & $\begin{array}{l}\text { Edwards and Marchetti } \\
\text { (1996), Hunt and Lipo } \\
\text { (2001, 2007), } \\
\text { McLaughlin (2005) }\end{array}$ \\
\hline Cause of "collapse" & $\begin{array}{l}\text { Overinvestment in moai; } \\
\text { overpopulation; } \\
\text { recklessness; } \\
\text { deforestation }\end{array}$ & $\begin{array}{l}\text { Historic introduction of } \\
\text { epidemic diseases }\end{array}$ & $\begin{array}{l}\text { Rainbird (2002), Hunt } \\
\text { (2007), Hunt and Lipo } \\
\quad(2007)\end{array}$ \\
\hline Chronology of "collapse" & $\begin{array}{l}\text { Precontact, A.D. } 1680 \\
\text { "event" }\end{array}$ & $\begin{array}{l}\text { Postcontact, A.D. } 1722- \\
1877\end{array}$ & $\begin{array}{l}\text { Rainbird (2002), Hunt and } \\
\quad \text { Lipo (2007) }\end{array}$ \\
\hline
\end{tabular}

${ }^{a}$ Interpretations and assumptions from Flenley and Bahn (2002, 2007), Diamond (2005, 2007).

${ }^{b}$ Selected sources providing evidence in support of a revised model for Rapa Nui prehistory.

$c$ A date of ca. A.D. 1200 represents the best current evidence for initial colonization based on radiocarbon dating. Rapa Nui may have been colonized earlier, but currently there is no reliable evidence to support a longer chronology.

Sources of fuel from wood were lost (Orliac 2000) and other negative consequences such as soil erosion may have followed, but important losses for subsistence remain open to doubt. For example, archaeological faunal assemblages show that wild resources, such as birds, whose habitat would be supported by forest were never a dominant part of the diet; they occur only in small frequencies even in the earliest deposits (Figure 1). Polynesians brought several cultivated plants with them, and subsistence, as elsewhere in Polynesia, relied largely on cultivation, chickens, and marine resources.

Some have speculated that the loss of the forest brought an end to deep-sea fishing as materials for seaworthy canoes disappeared. However, the palm trees, at least, were not a 

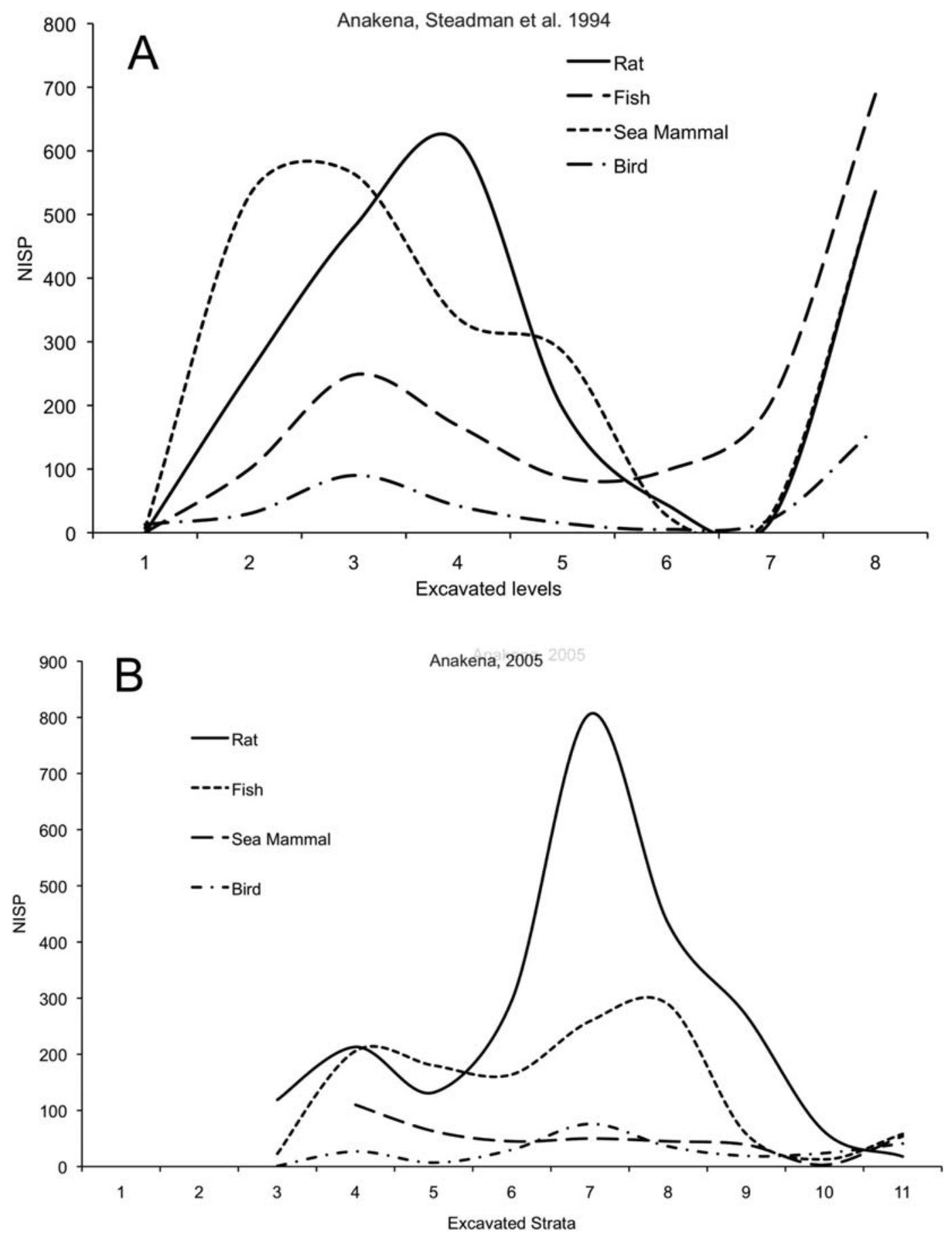

Figure 1. Faunal class data from Anakena Sand Dune excavations: $(A)$ from Steadman et al. (1994), $(B)$ from University of Hawai'i (2005 excavations). Faunal data from Skjolsvold (1994a,b) show comparable patterns. These faunal data reveal the abundance of rat (Rattus exulans), fish, and relatively smaller numbers (by NISP [number of identified specimens]) of bird. Contrary to common claims, sea mammals are common in the deposits and even abundant in later times. The horizontal axis shows excavated levels (arbitrary) or stratigraphic layers. Layers and levels are numbered consecutively from top to bottom so smaller numbers are younger, larger numbers older. 
likely source of wood for canoes given their fibrous interior and relatively thin, brittle bark. At least one tree on Rapa Nui (Alphitonia zizyphoides [see Orliac 2000]) could have provided suitable wood but only for smaller canoes because the largest known (mature) trees reach trunk diameters of $30-65 \mathrm{~cm}$. And using small canoes on the largely unprotected open seas off Rapa Nui would have often proven treacherous. This observation is supported by the archaeological evidence for marine subsistence. The fish remains from Anakena and other excavations comprise primarily inshore taxa (MartinssonWallin and Crockford 2002), with larger marine resources represented in sea mammals. Despite what some have claimed, the presence of sea-mammal bones does not necessarily indicate a deep-sea fishing strategy. In ethnographic cases, using small canoes in nearshore waters, or simply by swimming, we know that people take dolphins by striking stones together in nearshore waters to disorient the animals' echo-location system and driving them into shallow waters or on shore where they are killed (e.g., Bloch et al. 1990, Takegawa 1996, Porcasi and Fujita 2000). Sea-mammal bones from Anakena (the only location where they are reported in any quantity for the island) probably represent this specialized capture method, because it was reported for that location in the early twentieth century. It is also noteworthy that sea mammals do not disappear from the faunal record. Sea-mammal bones are present, even abundant, from multiple excavations in later prehistoric deposits at Anakena (see Figure 1), showing they were not depleted by overexploitation nor did people loose access to sea mammals as a result of deforestation. Resources such as dolphins were likely taken in occasional drives on to the sandy beach at Anakena-one of the very few places on the island where this strategy would be feasible. Deep-sea fishing appears never to have been a common subsistence strategy on Rapa Nui, with or without suitable trees for canoes.

As the forest disappeared on Rapa Nui over the course of 400 to 500 years, some negative consequences would likely have ensued. Comparative research on islands, par- ticularly on offshore islands of New Zealand, shows that invasive species like rats lead to changes in vegetation structure and the loss of birds, including seabirds (Fukami et al. 2006). Rats prey upon eggs, chicks, and even adult seabirds, as well as altering nesting habitats leading to their extirpation (e.g., Atkinson 1985). This has a cascading ecosystem effect because seabirds play an important role in nutrient cycling, so as they disappearedperhaps rapidly-perhaps major nutrient cycling to the soils of Rapa Nui would have been lost (e.g., Fukami et al. 2006). Yet recent research shows that even before seabirds and forest disappeared, the primeval soils of the island may well have been nutrient-poor (Louwagie et al. 2006). The implication is that deforestation did not turn fertile soil into poor soil; instead relatively poor soil got worse. In short, the impacts to environmental carrying capacity under dryland agriculture would likely have been minimal. This observation is relevant to arguments that Rapa Nui once supported a large human population that crashed as a result of humaninduced ecological impacts. It seems that the basic resources would never have supported a population as large (e.g., 15,000 or more) as Diamond (2005:90) and others have speculated.

Diamond (2007:1692) has claimed that deforestation induced changes in horticultural practices. However, he bases this supposition on extrapolating the findings from one area, the Poike Peninsula, to the entire island; he does this despite Mieth and Bork (2006:315) explicitly questioning whether their results could be validly extrapolated to the entire island. But Poike is a peculiar place in Rapa Nui because it has very little surface rock. Elsewhere, most of the island is covered by bedrock outcrops and a remarkably stony surface composed of volcanic cobbles and boulders. Poike is not the only area of early cultivation, as evidence throughout the island reveals closely contemporaneous use of fire, etc., beginning in the late thirteenth century (see Mann et al. 2003, 2008). Moreover, there is little evidence that "stone mulching" is exclusively an agricultural response to deforestation, or particularly to falling crop yields 


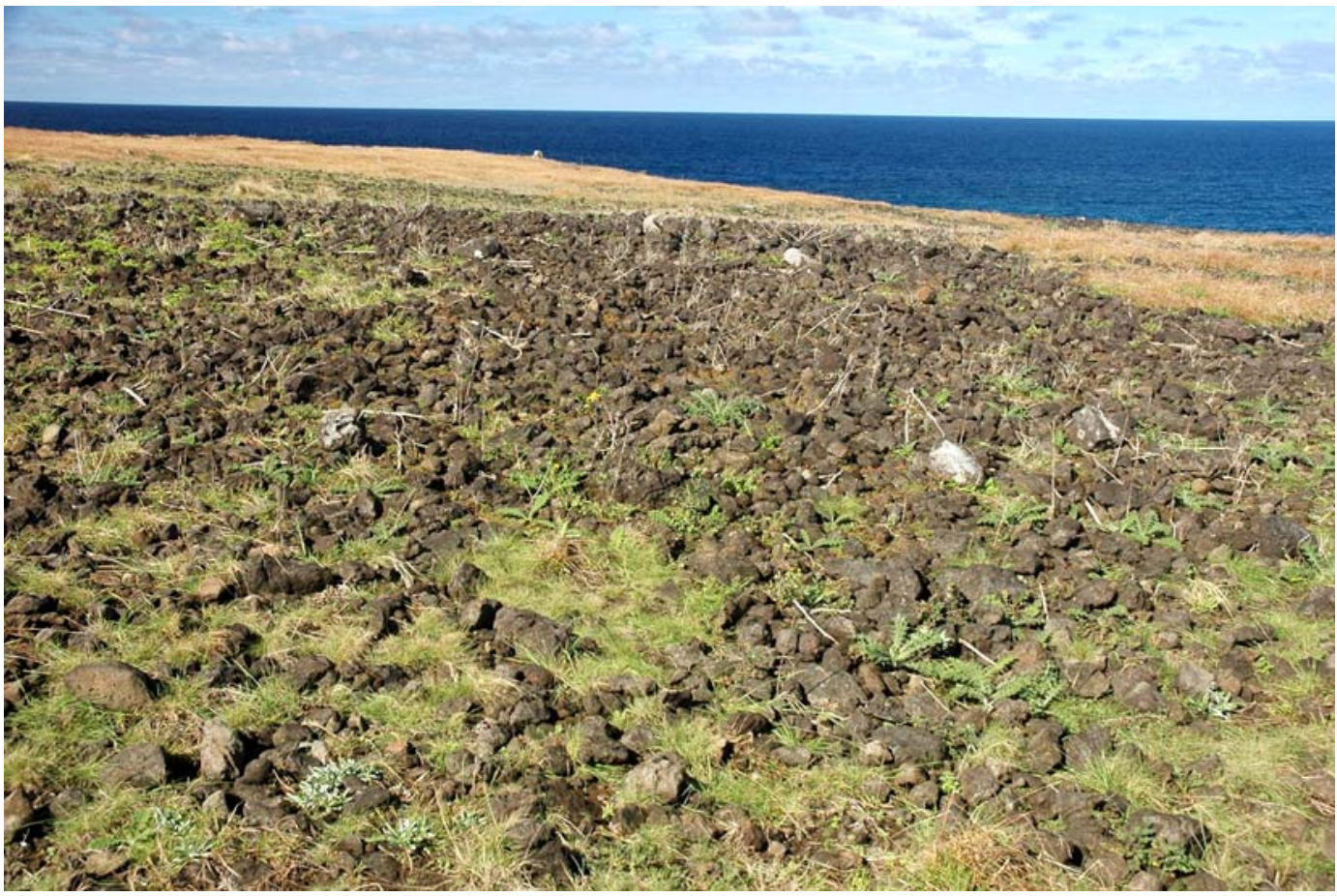

FigURE 2. An example of "stone mulch" agricultural fields at Akahanga (south coast) similar to those found over many areas of Rapa Nui.

(Figure 2). Indeed, based on current evidence stone mulching appears to develop at least 300 years before the forest disappeared (Stevenson et al. 1999). With or without forest, stone mulching was an engineering solution that optimized cultivation in nutrient-poor soils in the windswept and variable rainfall conditions of Rapa Nui.

As detailed research has shown, stone mulch minimized transpiration, moderated temperature, added essential nutrients, and mechanically protected crops against wind damage (Stevenson et al. 1999, Wozniak 1999, Bork et al. 2004). Stone mulch likely served to optimize stability (versus short term maximization) in agricultural production given the challenges of an unpredictable environment. Similar uses of "stone mulching" are documented in Hawai'i (Allen 2004; see also Kirch et al. [2004b, 2005] on nutrient depletion in soils) and in the desert Southwest United States (e.g., Maxwell 1995), where it enhanced crop productivity and served to minimize agricultural risk. Thus, it seems unlikely that stone mulch is best explained as evidence of a desperate effort to grow crops after failures induced by deforestation. At first impression, the stony surface of much of Rapa Nui is easily misinterpreted as a barren wasteland consistent with "ecocide." Some view rocks, from a Western agricultural perspective, as something to remove so that one can plow fields for monocropping. But on Rapa Nui the stone mulch was an ingenious method that provided cultigens with nutrients and functioned to retain soil moisture.

Diamond (2007:1692, italics added) suggested "that in the first phase, erosion was negligible, and horticulture was sustainable." This claim overlooks the chronological evidence and asserts a much longer chronology not evident for Rapa Nui. Precisely the lines of evidence that Diamond (2007:1693) suggested for dating the island's first settlement 
(i.e., first presence of Pacific rat, initial burning, changes in vegetation, and initial dates from several sites, etc.) consistently point to approximately A.D. 1200 as the start of colonization (see Mann et al. 2003, 2008, Mieth and Bork 2004, 2006, Hunt and Lipo 2006, 2007, 2008). Diamond (2007) nonetheless opined that the chronology of island settlement remains in question, implying that it may be many centuries longer. Taking this position allows him to speculate, in the absence of any reliable evidence, about a "first phase" of archaeologically invisible land use in support of the conventional scenario. Here the tacit assumption is that people arrived on the island centuries earlier, left no visible impacts to the island, and remained archaeologically invisible. Unfortunately, such a scenario calls on faith given the lack of evidence (see Anderson 1995; he describes simplistic notions of "cryptic settlement" in arguments made for long chronologies; also see Hunt and Lipo 2007, 2008).

Drawing on the detailed stratigraphic work of Mieth and Bork (2006), Diamond (2007:1692) cited a rate of soil erosion proceeding uphill $3 \mathrm{~m} / y e a r$, implying that this represents a constant rate of soil erosion for the entire island. It does not and cannot reasonably be extrapolated for the entire island (see Mieth and Bork 2006). This rate is estimated for the Poike Peninsula - an area of fairly steep terrain with unconsolidated volcanic ash soils and almost no surface rocks. As a consequence, that part of the island is particularly susceptible to erosion. It also remains unknown how much of this erosion followed grazing by thousands of sheep in the nineteenth century as well as modern efforts to farm the area with plowing. As Mieth and Bork (2006:289) reported for Poike, 7,00010,000 sheep grazed an area of about 900 ha from 1930 to 1960. The grassland of Poike was also burned annually during recent historic times (Mieth and Bork 2006), and grass fires are still common. Intensive historic use and abuse must have taken a huge toll with soil erosion, which continues today.

Recent stratigraphic research on ancient land use and soil erosion at Maunga Orito on the west side of the island shows that sub- stantial erosion with accumulation of colluvium occurred in just the last 100-200 years (Stevenson et al. 2006). Based on dating wood charcoal particles in colluvium (i.e., from eroded soil and redeposited sediment), even these age estimates suggest a maximum (yet recent) age estimate for these depositional events. It appears that much of the erosion at Maunga Orito took place over the historic period, perhaps quite late (nineteenth century), including a time when the island suffered serious impacts of sheep ranching (Fischer 2005:135-198). Such late erosion raises questions about the chronology of impacts to the landscape from deforestation relative to those from historic ranching activities. In the absence of detailed research distinguishing depositional events and their chronology, proclaiming a dramatic yet uniformly high rate of soil erosion that conflates effects from historic and prehistoric eras, as Diamond (2007:1692) does, has little validity.

\section{Rats and Deforestation}

Diamond (2005, 2007, Rolett and Diamond 2004) is correct in suggesting that Rapa Nui's deforestation can be understood in terms of environmental fragility. This fragility meant that the island's vegetation was vulnerable, more than that of other islands with greater biocomplexity, to the impacts of invasive species such as the introduced Pacific rat (Rattus exulans). Concerning the role of rats, Hunt (2007) suggested that we evaluate the relative contribution of rats, felling, and fire to the deforestation of the island. Hunt (2007) did not suggest that rats alone deforested the island; so it is disingenuous to suggest, as Diamond (2007:1693) did, that rats needed hatchets and matches to play a role in the island's ecological transformations.

It is worth noting that many islands have native forest that has persisted despite invasion by the Pacific rat (Diamond 2007:1693). However, a long list of islands with rats that were not deforested says little, if anything, about Rapa Nui. Each island is unique in its history, biodiversity, and biogeography (e.g., "rescue" effects). To argue a false and simple cause-effect that "rats mean deforestation" 
assumes that diverse islands shared the same history, biogeography, and ecology. Even as Diamond (1985:602) pointed out for island biota, "rats have caused catastrophic extinction waves on some islands, a few extinctions on others, and no visible effect on still others." Otherwise, Diamond (2007) and others (e.g., Flenley and Bahn 2007) should explain how rats-as an invasive species in a fragile ecosystem-could colonize successfully yet sustain no impact on Rapa Nui, and, by implication, that direct human actions were the sole source of ecological change.

Diamond (2007) also ignores the critical research in Hawaili by Athens et al. (2002; see also Athens 2008) that documents the dramatic role of the introduced Pacific rat in the rapid and extensive deforestation of native forest, including the predominant Pritchardia palms, shortly after the arrival of Polynesians. The paleoenvironmental evidence from Hawai' $i$ reveals that rats had an enormous impact on the lowland forests, even in those larger islands. Moreover, an extensive literature documents the profound impact of rats on vegetation, and ecosystems generally (e.g., Towns et al. 2006). These observations beg the question: what role did invasive rats play in Rapa Nui's deforestation? Indeed, the relative contribution of rats to deforestation on Pacific islands has yet to be fully explored.

Unfortunately, along these lines and perhaps in efforts to characterize the issue as simplistic, Diamond (2007:1693) framed the impact of rats as an all-or-nothing hypothesis. For example, he (Diamond 2007:1693) claimed, without documentation, that a larger number of palm nuts were burned rather than rat gnawed. Yet no one has quantified the number of burned versus rat-gnawed nuts sampled from deposits throughout the island (including all palm endocarps inspected in the Englert Museum that are rat gnawed [see Hunt 2007]). In any case, the observation that some nuts were burned and others were gnawed points to the potential of both rats and fire playing a role in the demise of the island's forest.

Diamond (2007:1693) and others (Flenley and Bahn 2007, Rolett 2008) assert that the extinct palms of Rapa Nui (Fubaea sp. or Paschalococos disperta) had a life span of up to 2,000 years. So if rats were the sole agent of deforestation, mature trees would still exist today. But a maximum life span of 2,000 years for these extinct palms remains nothing more than speculation. In a recent review Tomlinson (2006:10) pointed out that "the age of a palm can only be determined accurately from knowledge of its seed planting date. An iconic example is the famous specimen of Fubaea chilensis in the Temperate House at Kew [London], planted in 1843." Extrapolated ages published for 7ubaea palms range from only 100 to 740 years (Tomlinson 2006:10). Finally, it is worth noting that the Kew Garden fubaea palm growing in the equable conditions of a greenhouse (similar to the prime growing conditions of subtropical Rapa Nui?) is now 164 years old, and it is a large, adult tree now threatening to break the glass roof of Kew's Temperate House.

\section{Human Population and "Ecocide"}

Critical to the case for "ecocide" are estimates of changes in ancient population size and the timing of its decline. Diamond (2007:1693) cited a recent source (Vargas et al. 2006:232) as evidence of a pre-European contact "collapse." Based on obsidian hydration dates measured from samples taken from habitation sites $(n=922)$, Diamond argues that the occupation rises and falls, thus reflecting the collapsing population. However, within the period when deforestation progressed, about A.D. 1200 and 1700, the population appears to have continued to rise (Figure 3). Thus, based on at least this analysis (Vargas et al. 2006:232), it is apparent that as forest disappeared, the population grew. The first and only sign of sustained decline in the population-where decline is vital to Diamond's "ecocide" argument-occurs during an interval dated from A.D. 1750 to 1800 , after the arrival of the first European visitors. Contrary to the narrative that has emerged about a prehistoric collapse, a precipitous drop in the population with European contact is precisely what we would expect: as elsewhere in the Pacific and the New World, 


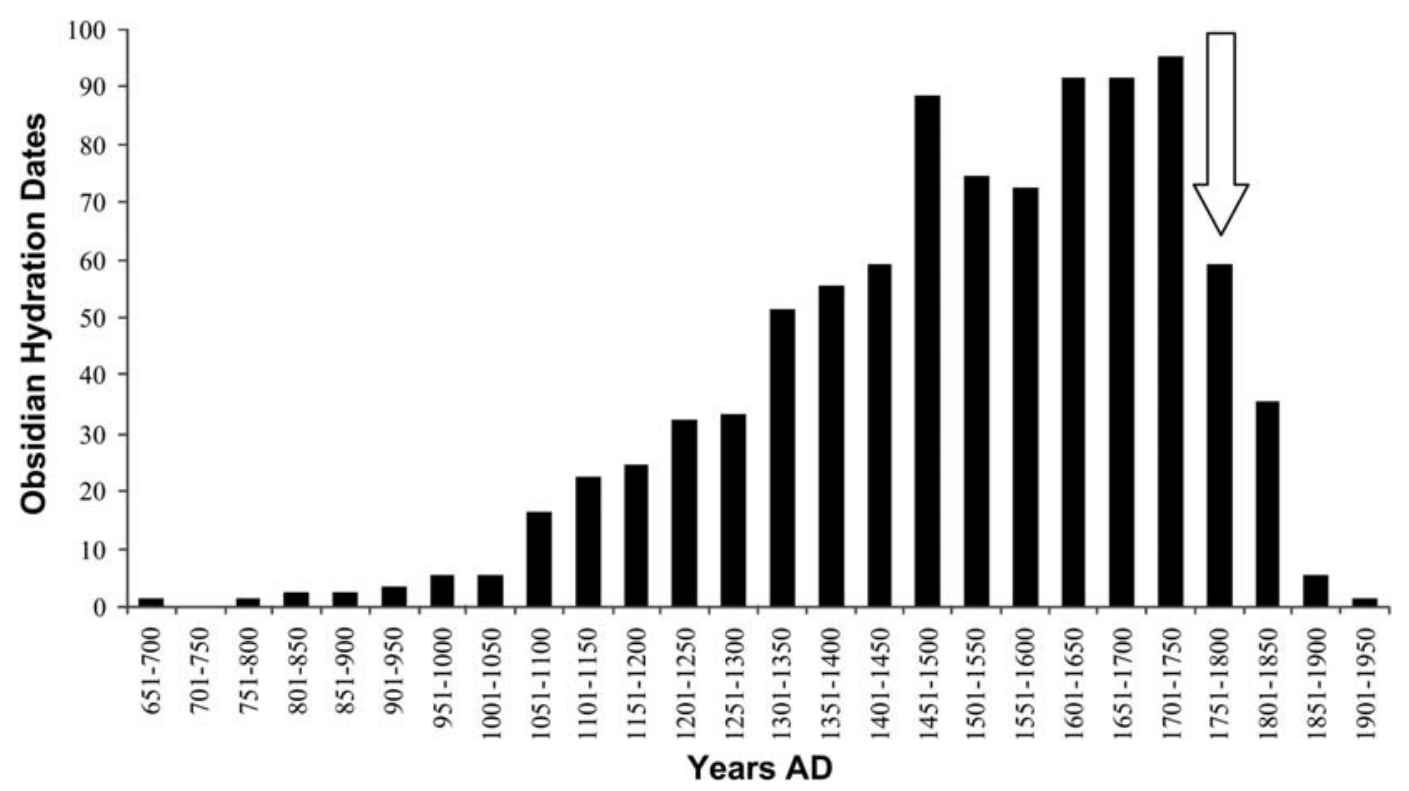

Figure 3. Habitations dated by obsidian hydration. Arrow indicates a dramatic decline in dated habitations in the historic (postcontact) period. These data do not support a hypothesis of precontact demographic collapse. Values are replotted from data provided by Vargas et al. (2006:232).

European germs wiped out many native populations lacking immunity to Old World diseases (e.g., Crosby 1972, 1986, Stannard 1991), as documented archaeologically (e.g., see Kirch [2007] for an exemplary study from Maui).

Rapa Nui's distribution of dated habitation sites lends support for a post-European contact depopulation event and provides at least ordinal-level information about the history of prehistoric population size, its growth, and collapse, but other problems warrant critical evaluation. This dated distribution of structures from Vargas et al. (2006:232) derives entirely from obsidian hydration measurements of flaked artifacts. Several problems inherent in the method suggest that the distribution may not provide an accurate absolute chronology. First, no valid hydration rate has been independently established for Rapa Nui obsidians. Attempts to do so have proceeded by comparing experimental hydration results with radiocarbon dates from associated excavation context (Stevenson 2000). Although increasingly sophisti- cated instruments are used to accurately measure hydration rims (e.g., Stevenson et al. 1998, 2001), two kinds of problems remain. First, the lack of any deterministic relationship between the events measured by radiocarbon and that of obsidian hydration means that establishing one with the other as if by "calibration" suffers from unacceptably low precision. Second, multiple factors can influence hydration of specimens and thus their "dating," so that inconsistent results cannot be adequately evaluated. As Anovitz et al. (1999) established, obsidian hydration cannot reliably provide interval-level chronological results. At best the method may show potential in large numbers as a relative measure of time. No amount of "recalibrating" hydration dates will produce a single value robust enough to warrant absolute chronological claims. Indeed, the establishment of ever "better" rates in the field or laboratory to match what is assumed about chronology risks a circular logic in employing obsidian hydration as an absolute dating method.

Regarding the early end of this sequence 
(Figure 3) using obsidian hydration, it is also worth noting that we cannot expect measurement error to be normally distributed. As the hydrated portion approaches zero (i.e., with the youngest samples), the measured rind will physically be biased more toward larger values than smaller ones (because negative numbers are obviously invalid). Thus the error will be toward older age estimates, not younger ones. A second concern is that any rate used to estimate age has some unspecifiable degree of error. And third, hydration rates likely vary by source and environment of deposition. In general, given the numbers of dates used to generate the distribution reported by Vargas et al. (2006) and the relatively short amount of time represented overall, it is likely that measurement and other sources of error added ages to the estimates, making chronological distributions left-skewed (i.e., too early). By chance alone, one would expect some of the dates to be too old. This would explain the small number of early obsidian dates (i.e., before ca. A.D. 1200 , when the island appears to have been first settled based on the radiocarbon chronology currently established [see Hunt and Lipo 2006]).

In sum, although we question the validity of details in the age distribution based on obsidian hydration, particularly toward the early end, it may nonetheless provide some glimpse of postcontact demographic collapse. A postcontact demographic collapse follows the predictable consequences of the introduction of Old World disease. "Ecocide" calls for a precontact, indeed even a "1680 AD" event (Diamond 2005; see also Ferdon 1961, Heyerdahl 1961), based on the spurious correlation of oral traditions and a radiocarbon date seen as the cumulative social consequences of deforestation and overexploitation of resources. The obsidian hydration evidence, albeit problematic, does not support a chronology for a precontact population collapse premised on "ecocide."

In support of arguments for a large prehistoric population-one that overshot the island's limited carrying capacity-Diamond (2007:1693) cited experiments reported by Van Tilburg and Ralston (2005) using a concrete-replica moai (statue) and shown in transport experiments on a NOVA television documentary (Love 2000). The assumption is that it took large numbers of people to make and especially move moai, as well as those who supported their efforts with agricultural surplus. Diamond (2007:1693) mistakenly referred to a 9-ton statue pulled a distance of 10 $\mathrm{km}$; he also suggested that the task would require 70 people, who in turn must have been fed by 400. These speculative extrapolations are used to argue that a population of thousands existed on at least one portion of the island. This is taken as support of a huge (i.e., well beyond carrying capacity) islandwide population. But to set the record straight, Van Tilburg and Ralston (2005:295) described two experiments pulling a 10-ton (not 9-ton) statue with a team (46 people, not 70) $110 \mathrm{~m}$ in pulls of 40 and $70 \mathrm{~m}$, and in the second attempt, just $50 \mathrm{~m}$ (not the 10 $\mathrm{km}$ cited).

But these figures are likely moot. Unfortunately, the experiments cannot prove the actual statue-moving methods used. Moreover, extrapolations from one method-never demonstrated-are used to speculate about population size that only heaps speculation upon speculation. It is also important to note that Van Tilburg and Ralston's (2005) experiment using an A-frame sled with sliders over $\log$ rails, or "canoe ladders," is plagued with problems, particularly in light of the coastal locations where statues were transported and erected (e.g., see Lee 1998, 1999). Our own field research (Lipo and Hunt 2005) and detailed observations (Sergio Rapu, pers. comm., 2005) on more than 50 "in transit" statues abandoned along the ancient roadways show that the moving experiments and the methods reconstructed from them have not drawn directly on patterns in the archaeological evidence for transport such as the roads and statues abandoned along them.

\section{REENVISIONING RAPA NUI'S PREHISTORY}

In contrast to a conventional view that has been promulgated for some time, we envision a different outline of prehistory based on current evidence (see Table 1). As we consider 
alternatives, evaluating them in empirically sufficient terms will be critical.

\section{Colonization Chronology}

Research now suggests that colonization of eastern Polynesian archipelagos such as the Cooks, Societies, Marquesas, and Hawaiian Islands first occurred around A.D. 900 to 1000. Based on higher standards for radiocarbon dating and its validity, these chronologies for eastern Polynesia are centuries later than have long been assumed (e.g., see Spriggs and Anderson 1993, Anderson and Sinoto 2002). Recent field research and reevaluation of radiocarbon dates show that New Zealand (e.g., Wilmshurst et al. 2008) and the distant islands of the Austral and Gambier groups were not colonized until after A.D. 10001200 (Kirch et al. 2004a, Kennett et al. 2006). In this last episode of migration, perhaps coincident with high frequencies of $\mathrm{El}$ Niño-Southern Oscillation events (Finney 1985, 2001, Anderson et al. 2006), Polynesian colonists first reached Rapa Nui. Based on chronology and geographic proximity, perhaps among other lines of evidence (Green 1998, 2000), migrations to Rapa Nui may have originated in the Gambier Group (Mangareva-Pitcairn region). The founding population may have been small, numbering somewhere around 50 people or less, but this is only conjecture.

\section{Population Growth and Size}

The rapid colonization of scores of islands over the vastness of the eastern Pacific demanded multiple migrations supported by a high population growth rate. As Birdsell (1957) pointed out, rapid colonization of islands requires population growth as a necessary foundation for migrations. From the historically documented population on Pitcairn after its recolonization by the Bounty mutineers and their mates, Birdsell (1957) showed that population growth rates of $3.4 \%$ and higher occur among human colonists. If a rate approaching this (e.g., 3.0\%) occurred with the first colonization of Rapa Nui, starting with only 50 people the island's population could reach 2,000 in just 123 years. Initial logistic growth rates would slow as the population reached a sustainable number. Based on Birdsell's data, demographic models, island population densities known for Polynesia, and early estimates of Rapa Nui population (see McCall 1994), we hypothesize that a sustainable number could be reached in less than two centuries, reaching about 3,000-4,000, attaining an intermediate density in the range of about 20 people per square kilometer. In this light, the high density of archaeological remains on Rapa Nui reflects 30-40 generations living on this small island and producing a dense palimpsest record often largely visible at the surface. Future paleodemographic research for Rapa Nui can be modeled on recent successes from Hawai' $i$ (e.g., Kirch 2007) and will necessarily address estimating a range for the island's population size.

\section{Deforestation}

Over the first century of human settlement on Rapa Nui the environmental impacts of rats and the use-and runaway effects-of fire would have initiated precipitous forest decline. The loss of trees, both in terms of mature individuals (fire and felling) and their recruitment (rats destroying seeds), may have been substantial. Although forest loss is unfortunate from a biodiversity perspective, these anthropogenic changes may have had little impact on overall agricultural productivity. Deforestation also meant habitat loss for native species, including what was certainly a large population of seabirds. Seabirds would have played a role in nutrient cycling enriching the soil of the island, but those soils were already nutrient-poor-a problem for agriculturalists since the island was first settled.

\section{Statues and Monuments}

Production and transport of statues as well as monument building began soon after the island was settled, although this and other dimensions of the archaeological record demand better chronological control. Early statues were variable in form and made from a 
variety of materials found across the island. As the industry developed, it became relatively standardized, and production focused more exclusively on the quarry at Rano Raraku. The major investments in architecture and statuary may have served the Rapa Nui population well in terms of mitigating violent competition and overpopulation (Hunt and Lipo 2001; see Dunnell 1999, Madsen et al. 1999). The evolution of such cultural elaborations can potentially be explained by evolutionary ecology and modeled as dimensions of "signaling" (e.g., Bliege Bird and Smith 2005), "advertising" (Neiman 1997), and "bet-hedging" (e.g., Madsen et al. 1999, Hunt and Lipo 2001), where ecological and evolutionary dimensions of explanatory models are complementary. In cultural and demographic terms, the human settlement of Rapa Nui can be regarded a success, more so than some kind of catastrophe-induced collapse.

\section{Demographic Collapse and Genocide}

The demographic collapse likely began as a consequence of the devastating effects of Old World disease (Crosby 1972, 1986, Dobyns 1993). The arrival of the Dutch in 1722 may have brought the first wave of epidemics, even as they remained invisible to Europeans. The next contacts occurred 48 years (about two generations) later with the arrival of the Spanish in 1770 and then the English in 1774. It is perhaps noteworthy that from Cook's 1774 visit onward, many of the descriptions of the island and its people are dismal. Was the impression formed by Cook and his crew a result of grave disease impacts from a Spanish visit just 4 years before? The genocide of the Rapa Nui population continued into the nineteenth century with slave trading, epidemics, and other devastating blows from colonialism on this small population.

\section{CONCLUDING THOUGHTS}

The details of this narrative will certainly change as basic archaeological and paleoenvironmental research continues on Rapa Nui. In contrast to a widespread impression, there remains much to be documented in the island's archaeology, paleoecology, and prehistory. But the point we wish to reiterate here is that the "conventional" accounts provided by some (e.g., Diamond 1995, 2005, 2007, Flenley and Bahn 2002) do not comport well with the existing evidence. Our concern is that a conventional narrative dominates, one that has unsubstantiated roots in modern myths (e.g., Heyerdahl 1961), and still frames much of what readers believe to be accurate about the island's prehistory. This narrative continually finds its way into popular and academic sources. We question the historical veracity and usefulness of these conventional accounts and invite open and critical research into this island's astonishing cultural and environmental story. Understanding what happened on Rapa Nui is important and likely to have broad implications for understanding human and environmental history. The dynamic story of this small, remote island has much to tell us. It is critical that we do our best to get it right.

\section{ACKNOWLEDGMENTS}

We thank David Addison, Atholl Anderson, J. Stephen Athens, Kelley Esh, Donald Grayson, Patrick Kirch, Alex Morrison, Sergio Rapu, John Terrell, Francisco Torres, and Janet Wilmshurst for sharing sources, thoughts, and comments generally on our research. We alone are responsible for the errors.

\section{Literature Cited}

Allen, M. S. 2004. Bet-hedging strategies, agricultural change, and unpredictable environments: Historical development of dryland agriculture in Kona, Hawaii. J. Anthropol. Archaeol. 23:196-224.

Anderson, A. 1995. Current approaches in East Polynesian colonisation research. J. Polynesian Soc. 104:110-132.

Anderson, A., J. Chappell, M. Gagan, and R. Grove. 2006. Prehistoric maritime migration in the Pacific Islands: An hypothesis of ENSO forcing. Holocene 16 (1): 1-6.

Anderson, A., and Y. Sinoto. 2002. New radiocarbon ages of colonization sites in 
East Polynesia. Asian Perspect. 41:242257.

Anovitz, L. M., J. M. Elam, L. R. Riciputi, and D. R. Cole. 1999. The failure of obsidian hydration dating: Sources, implications, and new directions. J. Archaeol. Sci. 26:735-752.

Athens, J. S. 2008. Rattus exulans and the catastrophic disappearance of Hawai'i's native lowland forest. Biol. Invas. 11 (7): 14891501.

Athens, J. S., H. D. Tuggle, J. V. Ward, and D. J. Welch. 2002. Avifaunal extinctions, vegetation change, and Polynesian impacts in prehistoric Hawai'i. Archaeol. Oceania 37:57-78.

Atkinson, I. A. E. 1985. The spread of commensal species of Rattus to oceanic islands and their effects on island avifaunas. Pages 35-81 in M. J. Moors, ed. Conservation of island birds: Case studies for the management of threatened island species. ICBP Technical Publications. Vol. 3. International Council for Bird Preservation, Cambridge, United Kingdom.

Barnes, S., L. Matisoo-Smith, and T. Hunt. 2006. Ancient DNA of the Pacific rat (Rattus exulans) from Rapa Nui (Easter Island). J. Archaeol. Sci. 33:1536-1540.

Birdsell, J. B. 1957. Some population problems involving Pleistocene man. Cold Spring Harbor Symp. Quant. Biol. 22:4769.

Bliege Bird, R., and E. A. Smith. 2005. Signaling theory, strategic interaction, and symbolic capital. Curr. Anthropol. 46 (2): 221-248.

Bloch, D., G. Desportes, K. Hoydal, and P. Jean. 1990. Pilot whaling in the Faroe Islands, July 1986-July 1988. North Atl. Stud. 2 (1, 2): 36-44.

Bork, H.-R., A. Mieth, and B. Tschochner. 2004. Nothing but stones? A review of the extent and technical efforts of prehistoric stone mulching on Rapa Nui. Rapa Nui J. 18:10-14.

Brander, J. A., and M. S. Taylor. 1998. The simple economics of Easter Island: Ricardo-Malthus model of renewable resource use. Am. Econ. Rev. 88:19-38.

Crosby, A. W., Jr. 1972. The Columbian exchange: Biological and cultural consequences of 1492. Greenwood Press, Westport, Connecticut.

. 1986. Ecological imperialism: The biological expansion of Europe, 9001900. Cambridge University Press, Cambridge.

Dalton, T. R., and R. M. Coats. 2000. Could institutional reform have saved Easter Island? J. Evol. Econ. 10 (5): 489-506.

De Monocol, P. B., E. R. Cook, D. Demeritt, A. Hornborg, P. V. Kirch, R. McElreath, and J. A. Tainter. 2005. Perspectives on Diamond's Collapse: How Societies Choose to Fail or Succeed. Curr. Anthropol. 46 (Suppl.): S91-S99.

Diamond, J. 1985. Rats as agents of extermination. Nature (Lond.) 318:602-603.

- 1995. Easter's end. Discover 9:6269.

- 2005. Collapse: How societies choose to fail or succeed. Viking, New York.

. 2007. Easter Island revisited. Science (Washington, D.C.) 317:1692-1694.

Dobyns, H. F. 1993. Disease transfer at contact. Annu. Rev. Anthropol. 22:273-291.

Dunnell, R. C. 1999. The concept of waste in an evolutionary archaeology. J. Anthropol. Archaeol. 18:243-250.

Edwards, E., and R. Marchetti. 1996. When the Earth trembled, the statues fell. Rapa Nui J. 10:1-15.

Ferdon, E. 1961. A summary of the excavated record of Easter Island prehistory. Pages 527-535 in T. Heyerdahl and E. N. Ferdon, eds. Archaeology of Easter Island. Monogr. Sch. Am. Res. Mus. N. Mex. 24 (1).

Finney, B. 1985. Anomalous westerlies, El Nino, and the colonization of Polynesia. Am. Anthropol. 87:9-26.

2001. Voyage to Polynesia's land's end. Antiquity 75:172-181.

Fischer, S. R. 2005. Island at the end of the world: The turbulent history of Easter Island. Reaktion Books, London.

Flenley, J. R., and P. Bahn. 2002. The enigmas of Easter Island. Oxford University Press, New York.

. 2007. Conflicting views of Easter Island. Rapa Nui J. 21:11-13. 
Fukami, T., D. A. Wardle, P. J. Bellingham, C. P. H. Mulder, D. P. Towns, G. W. Yeates, K. I. Bonner, M. S. Durrett, M. N. Grant-Hoffman, and W. M. Williamson. 2006. Above- and below-ground impacts of introduced predators in seabirddominated island ecosystems. Ecol. Lett. 9:1299-1307.

Gee, H. 2004. Environmental geography: Treeless at Easter. Nature (Lond.) 431:411.

Gibbons, A. 2006. Dates revise Easter Island history. Science (Washington, D.C.) 311:1360.

Green, R. C. 1998. Rapanui origins prior to European contact: The view from eastern Polynesia. Pages 87-110 in P. Vargas Casanova, ed., Easter Island and East Polynesian prehistory. Instituto de Estudios Isla de Pascua, Facultad de Arquitectura y Urbanismo, Universidad de Chile, Santiago.

- 2000. Origins for the Rapanui of

Easter Island before European contact: Solutions from holistic anthropology to an issue no longer much of a mystery. Rapa Nui J. 14:71-76.

Heyerdahl, T. 1961. An introduction to Easter Island. Pages 21-90 in T. Heyerdahl and E. N. Ferdon, eds. Archaeology of Easter Island. Monogr. Sch. Am. Res. Mus. N. M. 24 (1).

Hunt, T. L. 2006. Rethinking the fall of Easter Island: New evidence points to an alternative explanation for a civilization's collapse. Am. Sci. 94:412-419.

. 2007. Rethinking Easter Island's ecological catastrophe. J. Archaeol. Sci. 34:485-502.

Hunt, T. L., and C. P. Lipo. 2001. Cultural elaboration and environmental uncertainty in Polynesia. Pages 103-115 in C. M. Stevenson, G. Lee, and F. J. Morin, eds. Pacific 2000. Proceedings of the 5th International Conference on Easter Island and the Pacific. Easter Island Foundation, Los Osos, California.

. 2006. Late colonization of Easter Island. Science (Washington, D.C.) 311:1603-1606.

2007. Chronology, deforestation, and "collapse": Evidence vs. faith in Rapa Nui prehistory. Rapa Nui J. 21:85-97.
2008. Evidence for a shorter chronology on Rapa Nui (Easter Island). J. Isl. Coastal Archaeol. 3:140-148.

Kennett, D., A. Anderson, M. Prebble, E. Conte, and J. Southon. 2006. Prehistoric human impacts on Rapa, French Polynesia. Antiquity 80:1-15.

Kirch, P. V. 2007. Palaeodemography in Kahikinui, Maui: An archaeological approach. Pages 90-107 in P. V. Kirch and J.-L. Rallu, eds. The growth and collapse of $\mathrm{Pa}$ cific island societies: Archaeological and demographic perspectives. University of Hawai'i Press, Honolulu.

Kirch, P. V., J. Coil, A. S. Hartshorn, M. Jeraj, P. M. Vitousek, and O. A. Chadwick. 2005. Intensive dryland farming on the leeward slopes of Haleakala, Maui, Hawaiian Islands: Archaeological, archaeobotanical, and geochemical perspectives. World Archaeol. 37:240-258.

Kirch, P. V., J. Coil, M. I. Weisler, E. Conte, and A. J. Anderson. 2004a. Radiocarbon dating and site chronology. Pages 94-105 in E. Conte and P. V. Kirch, eds. Archaeological investigations in the Mangareva Islands (Gambier Archipelago), French Polynesia. Contribution No. 62, Archaeological Research Facility, University of California, Berkeley.

Kirch, P. V., A. S. Hartshorn, O. A. Chadwick, P. M. Vitousek, D. R. Sherrod, J. Coil, L. Holm, and W. D. Sharp. 2004b. Environment, agriculture, and settlement patterns in a marginal Polynesian landscape. Proc. Natl. Acad. Sci. U.S.A. 101:9936-9941.

La Pérouse, J. F. G. de. 1798. A voyage round the world performed in the years 1785 , 1786, and 1788. J. Johson, London.

Lee, V. R. 1998. Rapa Nui rocks: Impressions from a brief visit. Rapa Nui J. 12:69-72. . 1999. Rapa Nui rocks update. Rapa Nui J. 13:16-17.

Lipo, C. P., and T. L. Hunt. 2005. Mapping prehistoric statue roads on Easter Island. Antiquity 79:158-168.

Louwagie, G., C. M. Stevenson, and R. Langohr. 2006. The impact of moderate to marginal land suitability on prehistoric agricultural production and models of 
adaptive strategies for Easter Island (Rapa Nui, Chile). J. Anthropol. Archaeol. 25:290-317.

Love, C. 2000. More on moving Easter Island statues, with comments on the NOVA program. Rapa Nui J. 14:115-118.

Madsen, M., C. Lipo, and M. Cannon. 1999. Fitness and reproductive trade-offs in uncertain environments: Explaining the evolution of cultural elaboration. J. Anthropol. Archaeol. 18:251-281.

Mann, D., J. Chase, J. Edwards, R. Beck, R. Reanier, and M. Mass. 2003. Prehistoric destruction of the primeval soils and vegetation of Rapa Nui (Isla de Pascua, Easter Island). Pages 133-153 in J. Loret and J. T. Tanacredi, eds. Easter Island: Scientific exploration in the world's environmental problems in microcosm. Kluwer Academic/Plenum, New York.

Mann, D., J. Edwards, J. Chase, W. Beck, R. Reanier, M. Mass, B. Finney, and J. Loret. 2008. Drought, vegetation change, and human history on Rapa Nui (Isla de Pascua, Easter Island). Quat. Res. 69:16-28.

Martinsson-Wallin, H., and S. J. Crockford. 2002. Early settlement of Rapa Nui (Easter Island). Asian Perspect. 40 (2): 244-278.

Maxwell, T. D. 1995. The use of comparative and engineering analyses in the study of prehistoric agriculture. Pages 113-128 in P. A. Teltser, ed. Evolutionary archaeology: Methodological issues. University of Arizona Press, Tucson.

McCall, G. 1994. Rapanui: Tradition and survival on Easter Island. University of Hawai'i Press, Honolulu.

McLaughlin, S. 2005. Cannibalism and Easter Island: Evaluation, discussion of probabilities, and survey of the literature on the subject. Rapa Nui J. 19:30-50.

Mieth, A., and H.-R. Bork. 2004. Easter Island-Rapa Nui: Scientific pathways to secrets of the past. Man and Environment 1. Department of Ecotechnology and Ecosystem Development, Ecology Center, Christian-Albrechts-Universitat zu Kiel, Kiel, Germany.

. 2006. The dynamics of soil, landscape and culture on Easter Island (Chile). Pages 273-321 in J. R. McNeill and
V. Winiwarter, eds. Soils and societies: Perspectives from environmental history. White Horse Press, Isle of Harris, United Kingdom.

Neiman, F. D. 1997. Conspicuous consumption as wasteful advertising: A Darwinian perspective on spatial patterns in Classic Maya terminal monument dates. Pages 267-290 in C. M. Burton, G. Clark, and D. Bamforth, eds. Rediscovering Darwin: Evolutionary theory and archaeological explanation. Archaeol. Pap. Am. Anthropol. Assoc. 7.

Nunn, P. D., R. Hunter-Anderson, M. T. Carson, F. Thomas, S. Ulm, and M. J. Rowland. 2007. Times of plenty, times of less: Last-millennium societal disruption in the Pacific Basin. Hum. Ecol. 35:385-401.

Orliac, C. 2000. The woody vegetation of Easter Island between the early 14th and the mid-17th centuries A.D. Pages 211220 in C. Stevenson and W. Ayres, eds. Easter Island archaeology: Research on early Rapanui culture. Easter Island Foundation, Los Osos, California.

. 2003. Ligneux et palmiers de l'ile de Paques du XIeme au XVIIeme siecle de notre ere. Pages 184-199 in C. Orliac, ed. Archeologie en Oceanie insulaire: Peuplement, societes et paysages. Editions Artcom, Paris.

Peiser, B. 2005. From genocide to ecocide: The rape of Rapa Nui. Energy Environ. 16:513-539.

Porcasi, J. F., and H. Fujita. 2000. The dolphin hunters: A specialized prehistoric marine adaptation in the southern California Channel Islands and Baja California. Am. Antiq. 65:543-566.

Rainbird, P. 2002. A message for our future? The Rapa Nui (Easter Island) ecodisaster and Pacific island environments. World Archaeol. 33:436-451.

Redman, C. L. 2001. Human impacts on ancient environments. University of Arizona Press, Tucson.

Rolett, B. 2008. Avoiding collapse: PreEuropean sustainability on Pacific islands. Quat. Int. 184:4-10.

Rolett, B., and J. Diamond. 2004. Environmental predictors of pre-European defor- 
estation on Pacific islands. Nature (Lond.) 431:443-446.

Skjolsvold, A. 1994a. Archaeological investigations at Anakena, Easter Island. Pages 5-120 in A. Skjolsvold, ed. Archaeological investigations at Anakena, Easter Island. Vol. 3. The Kon Tiki Museum Occasional Papers, Oslo.

. 1994b. Appendix: Osteological analysis. Pages 203-211 in A. Skjolsvold, ed. Archaeological investigations at Anakena, Easter Island. Vol. 3. The Kon Tiki Museum Occasional Papers, Oslo.

Spriggs, M., and A. Anderson. 1993. Late colonisation of East Polynesia. Antiquity 67:200-217.

Stannard, D. E. 1991. The consequences of contact: Toward an interdisciplinary theory of native responses to biological and cultural invasion. Pages 519-539 in D. H. Thomas, ed. Columbian consequences. Vol. 3. The Spanish borderlands in Pan-American perspective. Smithsonian Institution Press, Washington, D.C.

Steadman, D. W., P. Vargas, and C. Cristino. 1994. Stratigraphy, chronology, and cultural context of an early faunal assemblage from Easter Island. Asian Perspect. 33 (1): 79-96.

Stevenson, C. M. 2000. Estimating Easter Island obsidian hydration rates from glass composition. Pages 205-210 in C. M. Stevenson and W. S. Ayres, eds. Easter Island archaeology: Research on early Rapanui culture. Easter Island Foundation, Los Osos, California.

Stevenson, C. M., I. M. Abdelrehim, and S. W. Novak. 2001. Infra-red photoacoustic and secondary ion mass spectrometry measurements of obsidian hydration rims. J. Archaeol. Sci. 28:109-115.

Stevenson, C. M., T. L. Jackson, A. Mieth, H.-R. Bork, and T. N. Ladefoged. 2006. Prehistoric and early historic agriculture at Maunga Orito, Easter Island (Rapa Nui), Chile. Antiquity 80:919-936.
Stevenson, C. M., B. Scheetz, and J. J. Mazer. 1998. Laboratory obsidian hydration rates: Theory, method, and application. Pages 181-204 in S. Shackley, ed. Archaeological obsidian studies: Methods and theory. Plenum Press, New York.

Stevenson, C., J. Wozniak, and S. Haoa. 1999. Prehistoric agricultural production on Easter Island (Rapa Nui), Chile. Antiquity 73:801-812.

Takegawa, D. 1996. The method of dolphin hunting and the distribution of teeth and meat: Dolphin hunting in the Solomon Islands 2. Pages 67-80 in T. Akimichi, ed. Coastal foragers in transition. Senri Ethnological Studies No. 42. National $\mathrm{Mu}-$ seum of Ethnology, Osaka.

Tomlinson, P. B. 2006. The uniqueness of palms. Bot. J. Linn. Soc. 151:5-14.

Towns, D. R., I. A. E. Atkinson, and C. H. Daugherty. 2006. Have the harmful effects of introduced rats on islands been exaggerated? Biol. Invas. 8:863-891.

Van Tilburg, J. A., and T. Ralston. 2005. Megaliths and mariners: Experimental archaeology on Easter Island. Pages 279303 in K. Johnson, ed. Onward and upward! Papers in honor of Clement $W$. Meigan. Stansbury Publications, Chico, California.

Vargas, P., C. Cristino, and R. Izaurieta. 2006. 1000 Años en Rapa Nui. Arqueología del asentamiento. Editorial Universitaria, Santiago de Chile.

Wilmshurst, J. M., A. J. Anderson, T. F. G. Higham, and T. H. Worthy. 2008. Dating the late prehistoric dispersal of Polynesians to New Zealand using the commensal Pacific rat. Proc. Natl. Acad. Sci. U.S.A. 105:7676-7680.

Wozniak, J. 1999. Prehistoric horticultural practices on Easter Island: Lithic mulched gardens and field systems. Rapa Nui J. 13:95-99.

Young, L. B. 1991. Easter Island: Scary parable. World Monitor August: 40-45. 